\title{
Morphology Analysis of the Scale Formed on Crofer 22APU Steel in Atmospheres Containing $\mathrm{SO}_{2}$
}

\author{
Z. Żurek • A. Jaroń • M. Homa
}

Received: 2 March 2011/Revised: 20 April 2011/Published online: 13 May 2011

(C) The Author(s) 2011. This article is published with open access at Springerlink.com

\begin{abstract}
This work presents the results of a morphology analysis of the scale formed on Crofer 22APU steel at high temperature in atmospheres containing $\mathrm{SO}_{2}$. The studies of steel oxidation were conducted on pre-oxidised and non-pre-oxidised steel within the temperature range of $700-900{ }^{\circ} \mathrm{C}$ in a mixture of air of a varying $\mathrm{SO}_{2}$ content and in pure air. In the case of oxidation in pure air it was established that on the surface of the Crofer 22APU a two-layer scale is formed. The outer layer of the scale contains $\mathrm{MnCr}_{2} \mathrm{O}_{4}$, whereas the inner layer contains $\mathrm{Cr}_{2} \mathrm{O}_{3}$. The scale formed in the atmosphere containing $\mathrm{SO}_{2}$ is also comprised of two layers (outer $\mathrm{MnCr}_{2} \mathrm{O}_{4}$ and inner $\mathrm{Cr}_{2} \mathrm{O}_{3}$ ). The analyses were carried out with the use of the ${ }^{35} \mathrm{~S}$ isotope. The analyses of the phase composition and morphology of the formed scale were conducted with the use of SEM/EDX and TEM.
\end{abstract}

Keywords Crofer 22APU $\cdot$ Scale morphology $\cdot$ Oxidation $\cdot \mathrm{SO}_{2} \cdot$ Air

\section{Introduction}

The ferritic steel Crofer 22APU is an appropriate material for the construction of inter-connectors in fuel cells of the SOFC type, since it possesses adequate mechanical and electrical properties within the temperature range of $600-800{ }^{\circ} \mathrm{C}$,

Z. Żurek · A. Jaroń $(\bowtie)$

Faculty of Chemical Engineering and Technology, Cracow University of Technology, ul. Warszawska 24, 31-155 Krakow, Poland e-mail: aj@chemia.pk.edu.pl

Z. Żurek

e-mail: zzurek@chemia.pk.edu.pl

M. Homa

Foundry Research Institute in Cracow, ul. Zakopianska 73, 30-418 Krakow, Poland e-mail: homa_m@interia.pl 
that is the work of inter-connectors [1,2]. Crofer 22APU contains a large amount of chromium, and therefore when exposed to high temperature conditions it oxidises and forms on its surface a protective layer of $\mathrm{Cr}_{2} \mathrm{O}_{3}$, thus effectively protecting the basis against the corrosive damage. Unfortunately, $\mathrm{Cr}_{2} \mathrm{O}_{3}$ which forms on the steel surface under high temperature conditions in the presence of oxygen may form a volatile $\mathrm{CrO}_{3}$. One of the methods of preventing this phenomenon from happening is an addition of manganese to the alloy. The presence of manganese in the steel results in the formation on the outer surface of the scale (on the border of the phases atmosphere/oxide scale) of a thin layer of manganese-chromium spinel $\left(\mathrm{MnCr}_{2} \mathrm{O}_{4}\right)$, thus effectively preventing the undesired phenomenon of $\mathrm{CrO}_{3}$ formation and evaporation. The spinel $\left(\mathrm{MnCr}_{2} \mathrm{O}_{4}\right)$ possesses good electrical conductivity comparable to the electrical conductivity of $\mathrm{Cr}_{2} \mathrm{O}_{3}$, and hence it does not constitute an additional ohm resistance, which is an extremely important parameter for the materials intended for the construction of inter-connectors.

The research works [3-5] on the behaviour of the steel of Crofer 22APU type at high temperatures proved that a large number of factors influence the rate of oxidation of Crofer 22APU steel, such as the composition of the atmosphere, temperature, surface treatment and the thickness of samples. The authors of this work conducted research works on the behaviour of Crofer 22APU steel in the atmosphere of air and of air containing $\mathrm{SO}_{2}$. The purpose of these research works was to verify the influence of various concentrations of $\mathrm{SO}_{2}$ on the morphology of the scales formed on Crofer22APU steel which was pre-oxidised and which was not pre-oxidised.

\section{Experimental Procedures}

\section{Material and Method of Conducting Research}

The commercial chrome steel with the Crofer 22APU trade symbol was used for the research. The chemical composition of the steel is presented in Table 1. As follows from Table 1, chromium is the dominant alloy additive. Small amounts of alloy additives of $\mathrm{Al}$ and $\mathrm{Si}$ are present since, as it was shown in the research [6], their large quantity in chrome steels leads to the increased rate of oxidation.

The samples for the research of the size of $15 \times 20 \times 1.5 \mathrm{~mm}$ were cut out of sheet metal $1.5 \mathrm{~mm}$ thick. The surface of the samples was polished with the 2000 grit sandpaper. The samples were washed in an ultrasonic cleaner and degreased with ethanol prior to experiments.

Table 1 Chemical composition of Crofer 22APU steel [5]

\begin{tabular}{lllllllll}
\hline \multicolumn{1}{l}{ Chemical composition $(\%$ wg } & \\
\hline $\mathrm{Fe}$ & $\mathrm{Cr}$ & $\mathrm{Mn}$ & $\mathrm{Ti}$ & $\mathrm{La}$ & $\mathrm{Al}$ & $\mathrm{Si}$ & $\mathrm{Cu}$ & $\mathrm{Ce}$ \\
$\mathrm{Bal}$. & 22.3 & 0.53 & 0.055 & 0.10 & 0.0056 & 0.10 & 0.0046. & 0.0009 \\
\hline
\end{tabular}




\section{Equipment}

Samples were exposed in the apparatus (described in [7]) intended for studying the kinetics of oxidation of metallic materials at a high temperature in the air atmosphere.

The process of oxidation of Crofer 22APU steel was conducted in the mixture of air $+n \mathrm{SO}_{2}$ (where $n=0.1,1.0,10.0 \%$ ). The samples were placed in a furnace, then the reaction zone was rinsed with argon, and the heating of the furnace to a desired temperature was initiated. When the appropriate temperature was achieved, the mixture of air $+\mathrm{SO}_{2}$ was introduced. The rate of gas flow amounted to $10 \mathrm{dm}^{3} / \mathrm{h}$. The oxidation process was carried out within a temperature range of $600-900{ }^{\circ} \mathrm{C}$. After the given exposure time elapsed, the samples were cooled down in the argon atmosphere. The analyses of the phase and chemical composition as well as morphology of the scale were conducted with the use of XRD, EDX, SEM and TEM.

Additionally radioisotope studies were conducted with the use of $\mathrm{SO}_{2}$ marked with the radioactive ${ }^{35} \mathrm{~S}$ sulphur isotope.

\section{Radioisotope Studies}

The purpose of the radiotracer experiments was to obtain information on the transportation of sulphur through the growing scale and on sulphur participation in the formation of the scale at an initial stage of its formation. The method of twostage oxidation was implemented in the experiments referring to analyses of the transportation of sulphur. The method consists of oxidising metal samples alternatively in a natural oxidant and then, without stopping the reaction, in an oxidant marked with a radioactive isotope.

Radioisotope studies were conducted with the use of sulphur dioxide marked with the isotope ${ }^{35} \mathrm{~S}$. The radioactive sulphur isotope, ${ }^{35} \mathrm{~S}$, emits $\beta^{-}$radiation of maximum energy of $167 \mathrm{keV}$. The half-life of the isotope is 87 days. The detection of ${ }^{35} \mathrm{~S}$ was conducted by taking measurements with the use of a GM meter with a mica window. The distribution of ${ }^{35} \mathrm{~S}$ in the oxidised samples was analysed with the autoradiographic method.

\section{Obtaining of Sulphur Dioxide Marked with Radioactive Isotope ${ }^{35} \mathrm{~S}$}

Sulphur dioxide marked with a radioactive sulphur isotope was obtained by the way of reduction of sulphuric acid marked with ${ }^{35} \mathrm{~S}_{1} \mathrm{H}_{2}{ }^{35} \mathrm{SO}_{4}$, elementary sulphur. In order to achieve this, concentrated sulphuric acid was heated together with an acid marked with spectrally pure sulphur. Prior to heating, the whole set was rinsed with argon in order to eliminate oxygen, and then with natural $\mathrm{SO}_{2}$.

The synthesis of ${ }^{35} \mathrm{SO}_{2}$ proceeded in accordance with the following equation:

$$
\mathrm{S}_{8}+16 \mathrm{H}_{2}{ }^{35} \mathrm{SO}_{4}=8 \mathrm{SO}_{2}+16{ }^{35} \mathrm{SO}_{2}+16 \mathrm{H}_{2} \mathrm{O}
$$

The obtained gas was liquefied in two pipe coils at a temperature of $-50{ }^{\circ} \mathrm{C}$ and, in order to eliminate contamination, it was rinsed with helium, and then collected in a steel bottle containing $100 \mathrm{~g}$ of natural sulphur dioxide, cooled down to a 
temperature of $-70{ }^{\circ} \mathrm{C}$. The pipe coil and the bottle were cooled with a mixture of liquid nitrogen and ethylene alcohol. $8 \mathrm{mCi} \mathrm{H}_{2}{ }^{35} \mathrm{SO}_{4}$ was used as a reaction substrate. The process yield amounted to approximately $85 \%$. The specific radioactivity of the obtained gas amounted to approximately $70 \mu \mathrm{Ci} / \mathrm{g}$. After the reaction was completed, the set was rinsed again in natural sulphur dioxide. Figure 1 illustrates the block diagram of apparatus used to obtain ${ }^{35} \mathrm{SO}_{2}$.

In order to determine sulphur participation in the process of scale formation, the following experiment types were carried out:

1. In order to verify whether during the oxidation there is a transport of sulphur towards the metallic core, the steel samples were oxidised initially in natural $\mathrm{SO}_{2}$, and then, without stopping the reaction, in $\mathrm{SO}_{2}$ marked with ${ }^{35} \mathrm{~S}$.

The oxidised samples were dipped in acrylic resin. As the scales were very thin, the samples were cut at an angle of $45^{\circ}$ to the metal surface and metallographic specimens were produced. The detection of the radioactive sulphur isotope was conducted with the use of a GM meter and with a method of making autoradiograms of sample specimens. Figure 2 presents an autoradiogram of a specimen of a cross section of a steel sample oxidised for $170.5 \mathrm{~h}$ in $\mathrm{SO}_{2}$ under a pressure of $10^{5} \mathrm{~Pa}$, and then for $23.5 \mathrm{~h}$ in ${ }^{35} \mathrm{SO}_{2}$ at a temperature of $800{ }^{\circ} \mathrm{C}$. The dark parts of the autoradiogram indicate the places where ${ }^{35} \mathrm{~S}$ is present.

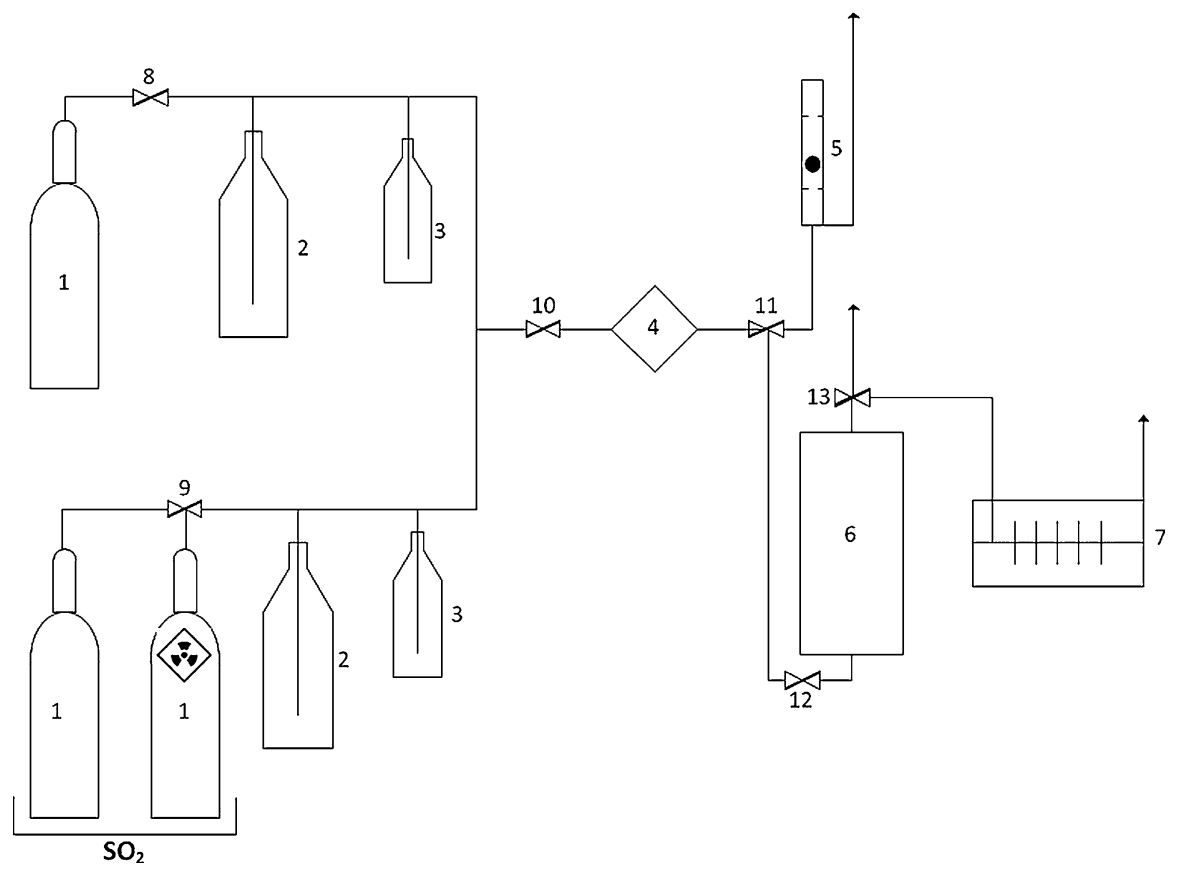

Fig. 1 Block diagram of apparatus used for two-stage oxidation: 1 bottle with gases, 2 manostats filled with $\mathrm{H}_{3} \mathrm{PO}_{4}, 3$ capillary flow regulators, 4 driers filled with $\mathrm{P}_{2} \mathrm{O}_{5}, 5$ gas flow meter, 6 quartz furnace, 7 rinsers filled with a solution of $\mathrm{KOH}, 8-13$ vacuum taps 


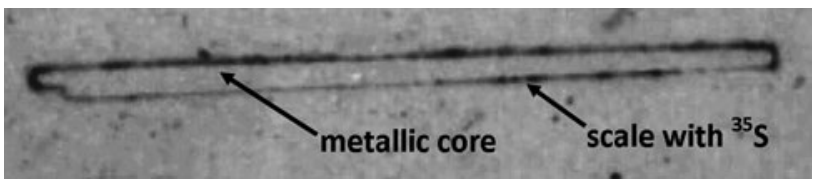

Fig. 2 Autoradiogram of diagonal cross-section of Crofer 22APU steel sample oxidized in two stages at a temperature of $800{ }^{\circ} \mathrm{C}$ for $170.5 \mathrm{~h}$ in $\mathrm{SO}_{2}$ and next for $23.5 \mathrm{~h}$ in ${ }^{35} \mathrm{SO}_{2}$

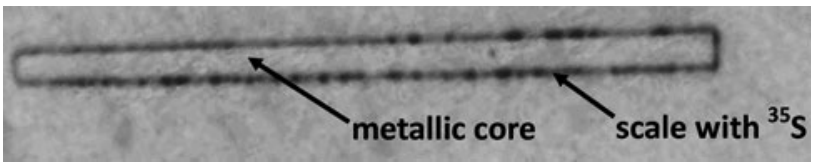

Fig. 3 Autoradiogram of diagonal cross-section of Crofer 22APU steel sample oxidized in two stages for $200 \mathrm{~h}$ in air at a temperature of $900{ }^{\circ} \mathrm{C}$ and next for $18 \mathrm{~h}$ in ${ }^{35} \mathrm{SO}_{2}$ at a temperature of $800{ }^{\circ} \mathrm{C}$

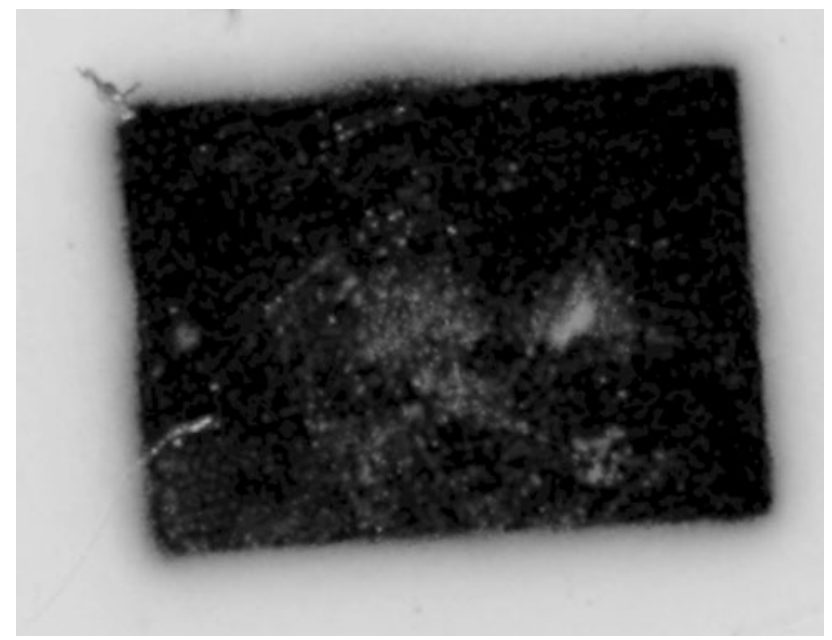

Fig. 4 Autoradiogram from surface of Crofer 22APU steel sample oxidized for $1.5 \mathrm{~h}$ in ${ }^{35} \mathrm{SO}_{2}$ at a temperature of $800{ }^{\circ} \mathrm{C}$

2. In order to determine whether there is a transport of sulphur (or $\mathrm{SO}_{2}$ ) towards the metallic core through the oxide layer formed at the first stage of the process, the steel sample was oxidised for $200 \mathrm{~h}$ in air at a temperature of $900{ }^{\circ} \mathrm{C}$, and then for $18 \mathrm{~h}$ in ${ }^{35} \mathrm{SO}_{2}$ under a pressure of $10^{5} \mathrm{~Pa}$ at a temperature of $800{ }^{\circ} \mathrm{C}$. Afterwards the sample was treated similarly like in the point 1 . Figure 3 illustrates an autoradiogram of a specimen of a cross section of a sample obtained in such a way.

3. In order to establish whether sulphur takes part in the formation of the scale formed at an initial stage of steel corrosion in $\mathrm{SO}_{2}$, the steel sample was oxidised in ${ }^{35} \mathrm{SO}_{2}$ for $1.5 \mathrm{~h}$ at a temperature of $800{ }^{\circ} \mathrm{C}$, and then an autoradiogram from the sample surface was formed (Fig. 4). 
Table 2 Results of numerical measurements of oxidized samples surfaces

\begin{tabular}{lll}
\hline No. & Oxidation condition & Counts (imp/s) \\
\hline 1. & $170.5 \mathrm{~h} \mathrm{SO}_{2}+23.5 \mathrm{~h}^{35} \mathrm{SO}_{2}\left(800{ }^{\circ} \mathrm{C}\right)$ & $2.05 \pm 0.07$ \\
2. & $200 \mathrm{~h}$ air $\left(900{ }^{\circ} \mathrm{C}\right)+18 \mathrm{~h} \mathrm{in}{ }^{35} \mathrm{SO}_{2}\left(800{ }^{\circ} \mathrm{C}\right)$ & $2.70 \pm 0.08$ \\
3. & $1.5 \mathrm{~h}^{35} \mathrm{SO}_{2}\left(800{ }^{\circ} \mathrm{C}\right)$ & $1.05 \pm 0.05$ \\
\hline
\end{tabular}

Apart from preparing autoradiograms, the detection of ${ }^{35} \mathrm{~S}$ was carried out by way of taking meter measurements from sample surfaces. Table 2 presents the results of meter measurements from the surfaces of the oxidised samples.

The research works with the use of TEM aiming to identify the presence of sulphur on the surface of the scale required special sample preparation. After oxidising in an atmosphere containing sulphur, the sample was coated with a thin layer of carbon, then with a layer of chromium, and finally with a layer of platinum. Such a course of action resulted from the fact that the characteristic radiation lines of sulphur overlap with the characteristic radiation lines of Pt. In order to avoid their overlapping it was necessary to separate the scale surface with a potential presence of sulphur from the platinum surface; it was necessary to put a carbon coating, and then a chromium coating. A sample prepared in such a way guaranteed that identified reflexes may originate from sulphur.

\section{Results and Discussion}

Sulphur dioxide $\left(\mathrm{SO}_{2}\right)$ may be present as a contaminant both in the anodic and cathodic atmosphere of a fuel cell SOFC. Thermodynamic considerations indicated that $\mathrm{SO}_{2}$ may form in the anodic area of the cell in the reaction of $\mathrm{H}_{2} \mathrm{~S}$ with oxygen in accordance with the reaction (2), but its concentration is negligibly low [8].

$$
\mathrm{H}_{2} \mathrm{~S}+3 \mathrm{O}_{2} \leftrightarrow \mathrm{H}_{2} \mathrm{O}+\mathrm{SO}_{2} \quad \Delta \mathrm{G}^{\mathrm{o}}=-982,6528 \mathrm{~kJ}
$$

whereas, sulphur in the cathodic atmosphere may be related to the presence of $\mathrm{SO}_{2}$. In the cathodic zone the probability of the presence of $\mathrm{SO}_{2}$ is considerably higher, since its presence may result from the contamination of air with this compound. Table 3 presents the values for oxygen and sulphur pressure in the mixture of air and a varying amount of $\mathrm{SO}_{2}$, calculated using FactSage program with thermodynamically data bases [8].

As can be concluded from the calculations, the presence of slight amounts of $\mathrm{SO}_{2}$ in the air practically exerts no impact on oxygen pressure. Oxygen partial pressure changes with temperature only to a small degree. In the case of sulphur, its partial pressure values change both as a concentration function of $\mathrm{SO}_{2}$ in gas and of temperature. The scale of the changes in pressure of sulphur vapours $\left(\mathrm{pS}_{2}\right)$ as a function of concentration of $\mathrm{SO}_{2}$ amounts to approximately three orders for each temperature taken into consideration. However, as a function of temperature the values $\left(\mathrm{pS}_{2}\right)$ change by even ten orders of magnitude. 


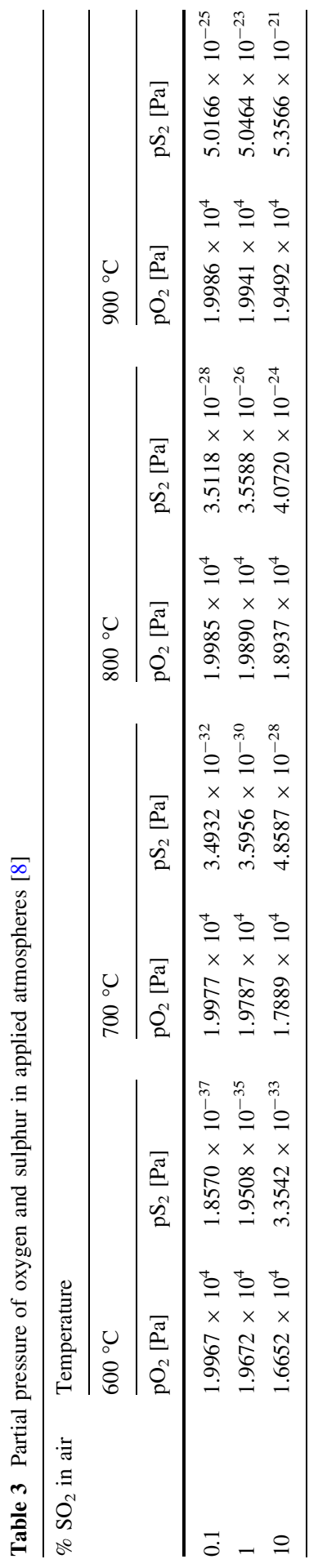



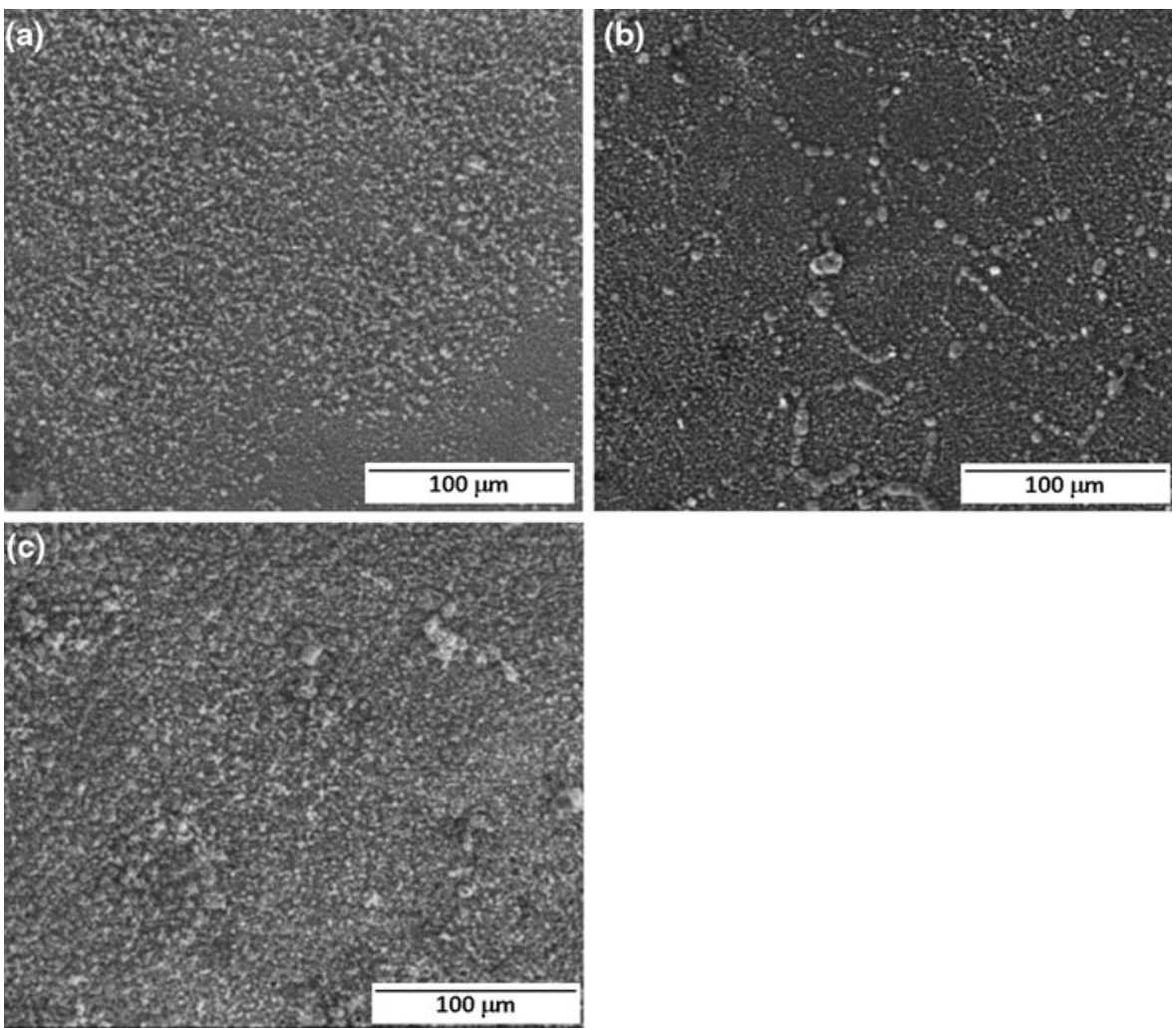

Fig. 5 Morphology (SEM) of sample surfaces of Crofer 22APU steel oxidized for $100 \mathrm{~h}$ in air atmosphere at a temperature of: a $700{ }^{\circ} \mathrm{C}, \mathbf{b} 800{ }^{\circ} \mathrm{C}$, c $900{ }^{\circ} \mathrm{C}$

The scale formed on all of the analysed samples demonstrates good adherence to the metallic core. The morphology of outer surface of the scale changes together with a change in temperature. At a temperature of 700 and $800{ }^{\circ} \mathrm{C}$ it is fine-grained and without clear crystalline structures. A preferential growth of the scale along the grain boundaries can be observed at a temperature of $800{ }^{\circ} \mathrm{C}$, whereas at a temperature of $900{ }^{\circ} \mathrm{C}$ all of the scale is covered with fine-grained crystallites (Fig. 5). The outer surface of the scales formed at the same temperature but in various atmospheres is practically the same as far as its structure is concerned.

The analyses of the phase composition showed that the forming scale consists mainly of $\mathrm{Cr}_{\mathrm{x}} \mathrm{O}_{\mathrm{y}}$ and the spinel $\mathrm{MnCr}_{2} \mathrm{O}_{4}$. The sample specimens accomplished after oxidation and the analysis of the chemical composition of the scales demonstrated that at temperatures of 600 and $700{ }^{\circ} \mathrm{C}$ the scale practically consists of a mixture of the spinel $\left(\mathrm{MnCr}_{2} \mathrm{O}_{4}\right)$ and chromium oxide $\left(\mathrm{Cr}_{2} \mathrm{O}_{3}\right)$. The amount of chromium oxide is larger in the scale near the border of the phases metal/scale. At temperatures of 600 and $700{ }^{\circ} \mathrm{C}$ the clear border dividing the outer and inner layers was not observable this does not mean that at these temperatures a two-layer scale does not form. The outer layer is very thin. At temperatures of 800 and $900{ }^{\circ} \mathrm{C}$ a two-layer 
scale forms; the outer layer is the spinel $\left(\mathrm{MnCr}_{2} \mathrm{O}_{4}\right)$ and the inner layer consists mainly of $\mathrm{Cr}_{2} \mathrm{O}_{3}$. On all of the analysed scale surfaces obtained within the temperature range of 600 and $700{ }^{\circ} \mathrm{C} \mathrm{TiO}_{2}$ in the form of separate grains was sporadically identified.

Figure 6 illustrates an example of (TEM) cross sections of steel samples oxidised at a temperature of $800{ }^{\circ} \mathrm{C}$ in various times and atmospheres. The sample oxidised for the time of $200 \mathrm{~h}$ in air atmosphere is covered with a scale layer slightly thinner than the sample oxidised for the time of $200 \mathrm{~h}$ in air atmosphere and then for $100 \mathrm{~h}$ in the atmosphere of air $+1 \% \mathrm{SO}_{2}$ and thicker than the sample oxidised only for $100 \mathrm{~h}$ in the atmosphere of air $+\mathrm{SO}_{2}$. As can be concluded from the analysis of the picture, no change in scale morphology was observed when the composition of the atmosphere was changed. The thickness of the scale alters mainly for the reason of the extended exposure time.
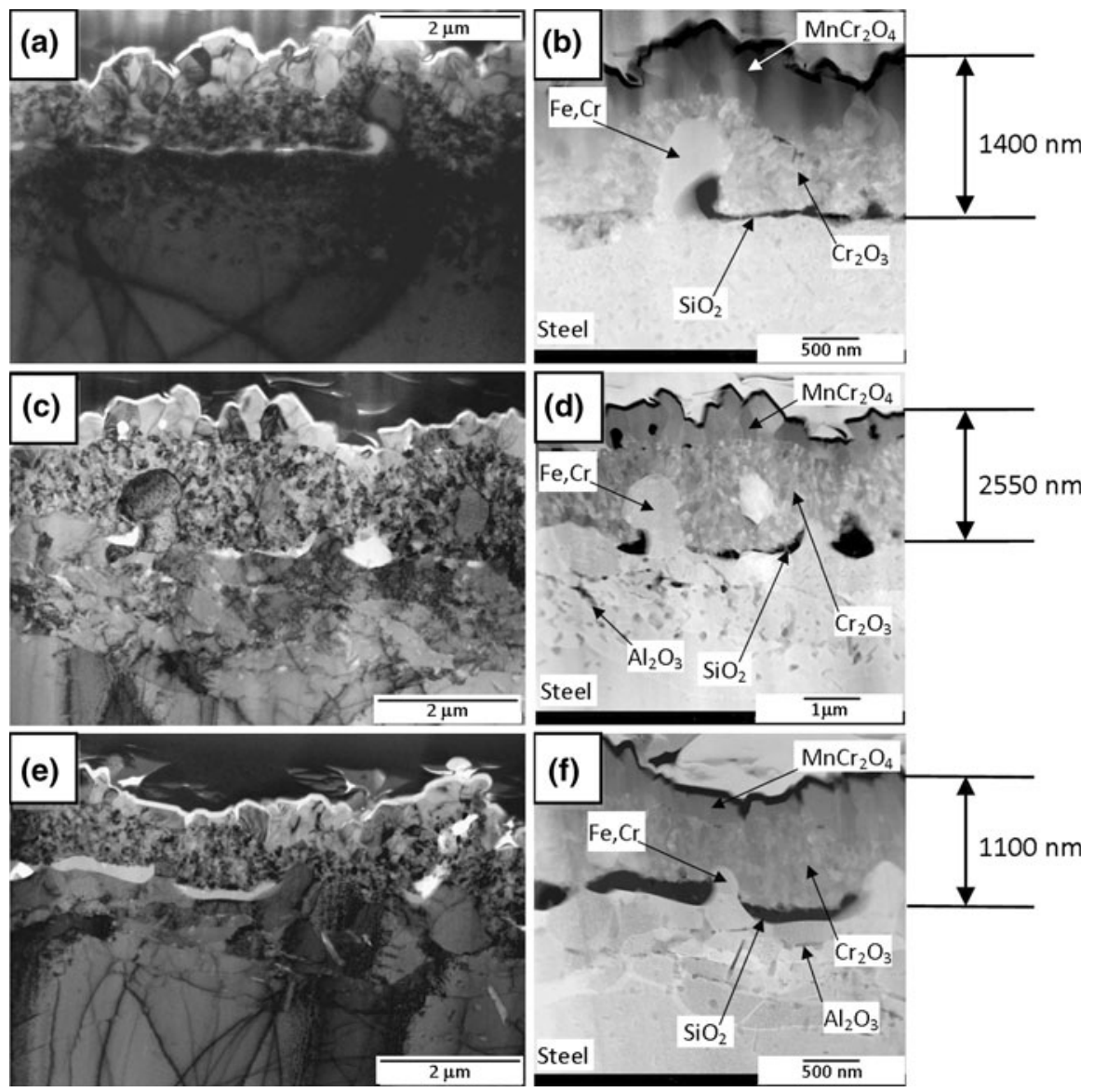

Fig. 6 Cross-section (TEM) of steel sample Crofer $22 \mathrm{APU}$ oxidized at a temperature of $800^{\circ} \mathrm{C}$ in: $\mathbf{a}$, b air for $200 \mathrm{~h}$; c, $\mathbf{d}$ air for $200 \mathrm{~h}$ and next in air $+1 \% \mathrm{SO}_{2}$ for $100 \mathrm{~h}$; e, f air $+1 \% \mathrm{SO}_{2}$ for $100 \mathrm{~h}$ 
In the subsurface of the metallic core an area of internal oxidation formed. Amorphous $\mathrm{SiO}_{2}$ is released on the border scale/metal, whereas $\mathrm{Al}_{2} \mathrm{O}_{3}$ in a dispersed form in the subsurface of the core.

The presence depletion of the chromium in the subsurface of metallic core was not identified, which proves that Crofer 22APU possesses a sufficient amount of chromium to maintain a stable layer of chromium oxide. In the inner layer of the scale on the border scale/metal one may identify metallic projections originating from the metallic basis, which act as anchors connecting the scale with the metallic basis (Fig. 7). Their composition differs significantly from the composition of the initial steel. These projections contain practically no $\mathrm{Mn}$ or other alloy additives, and are of a considerably low $\mathrm{Cr}$ content. They are formed as a result of extrusion of the metal out of the core, as the oxides $\mathrm{Al}_{2} \mathrm{O}_{3}$ forming within the core lead to an increase in tensions in this area. The structure has a tendency to annihilate the tensions and thus extrusion of the metal outside.

The results of the isotope studies indicate that at an initial stage of the reaction sulphur contributes to the formation of the scale (Fig. 4). Sulphur activity after the dissociation of $\mathrm{SO}_{2}$ is too low to enable the formation of sulphides in the reaction of sulphur with metals, probably at the beginning of the reaction, when the activity of metals is high, they enter into a reaction with sulphur dioxide:

$$
3 \mathrm{Me}+\mathrm{SO}_{2}=\mathrm{MeS}+2 \mathrm{MeO}
$$

In the autoradiograms of the cross sections of the samples undergoing a two-stage oxidation (Figs. 2, 3) one can observe throughout the scale dark places which
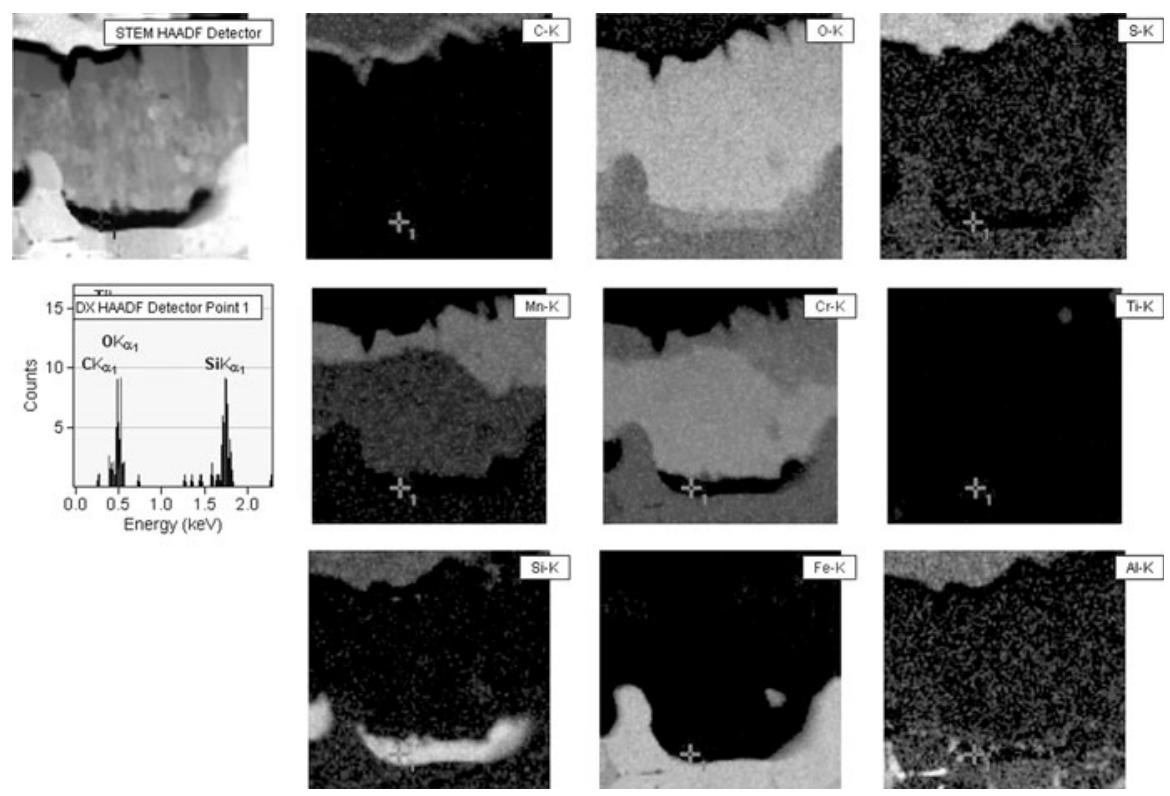

Fig. 7 Cross-section (TEM) and map of distribution of elements in (EDS) steel sample of Crofer 22APU oxidized at a temperature of $800{ }^{\circ} \mathrm{C}$ in air $+1 \% \mathrm{SO}_{2}$ for $100 \mathrm{~h}$ 


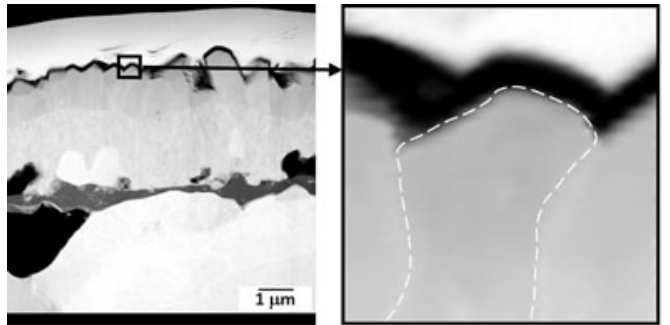

C-K

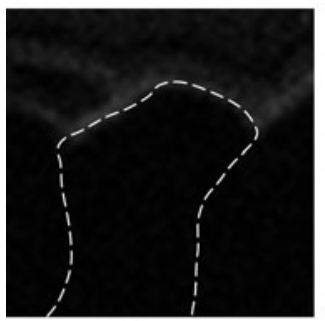

O-K

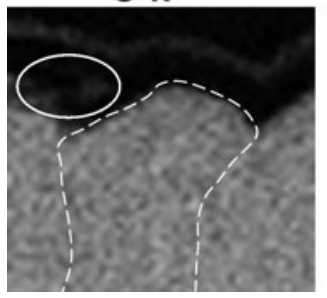

Cr-K

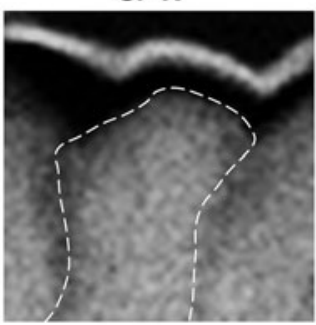

Pt-K

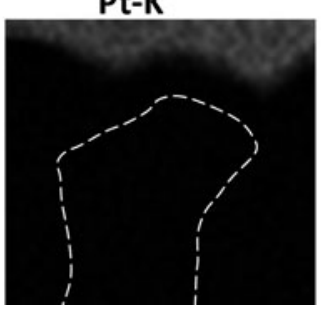

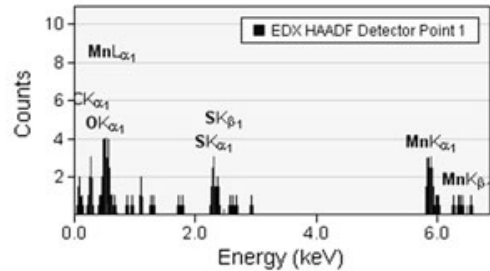

Mn-K

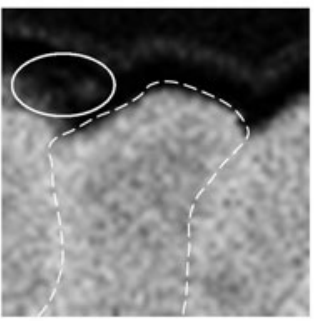

S-K

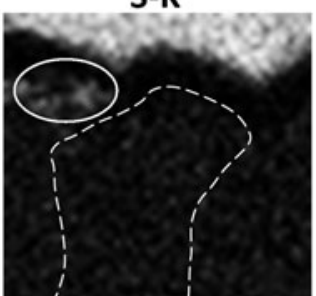

Fig. 8 Cross-section (TEM) and map of distribution of elements in (EDS) steel sample of Crofer 22APU pre-oxidized $\left(200 \mathrm{~h}, 800{ }^{\circ} \mathrm{C}\right.$, air) and sulphurized in atmosphere air $+10 \% \mathrm{SO}_{2}$ for $100 \mathrm{~h}$

confirm the presence of radioactive sulphur which was introduced into the reaction environment in its second stage. The distribution of sulphur is not uniform, and grains of compounds containing sulphur are visible.

Due to the fact that the scales are very thin, on the basis of the obtained results one cannot definitely conclude whether during the reaction time there is a transport of sulphur or $\mathrm{SO}_{2}$ towards the core. It is also impossible to establish in which form sulphur is bound in the scale. One can only assume that a slight quantity of manganese sulphide is formed.

The presence of sulphur on the outer surface of the scale layer was identified with the use of the EDX analysis (Figs. 7, 8). No sulphur was identified within the scale layer. The spinel $\mathrm{MnCr}_{2} \mathrm{O}_{4}$ is thermodynamically stable under such conditions and one should not assume that sulphur coming from the dissociation of sulphur dioxide and/or a sulphur dioxide could enter into reactions with it forming chromium sulphide and manganese sulphide. Also oxides of these metals cannot form sulphides according to the reactions below $(4,5)$, because for $1073 \mathrm{~K}, \Delta \mathrm{G}^{\mathrm{o}}>0$ (all $\Delta \mathrm{G}^{\mathrm{o}}$ values in this paper were calculated using FactSage program with thermodynamically data bases [8]). 


$$
\begin{aligned}
& 2 \mathrm{MnO}+2 \mathrm{SO}_{2} \rightarrow 2 \mathrm{MnS}+3 \mathrm{O}_{2} \Delta \mathrm{G}^{\mathrm{o}}=380,394 \mathrm{~kJ} \\
& 2 \mathrm{Cr}_{2} \mathrm{O}_{3}+4 \mathrm{SO}_{2} \rightarrow 4 \mathrm{CrS}+7 \mathrm{O}_{2} \Delta \mathrm{G}^{\mathrm{o}}=1161,746 \mathrm{~kJ}
\end{aligned}
$$

TEM analyses and the EDX analysis demonstrated (Fig. 8) that in the area of the scale outer surface identified sulphur is always accompanied by $\mathrm{Mn}$ and $\mathrm{O}_{2}$. $\mathrm{Mn}$ quickly diffuses through the scale layer (probably by grain boundary) [9-11] and on the surface it reacts with $\mathrm{SO}_{2}$ forming $\mathrm{MnS}$ and $\mathrm{MnO}$ in accordance with the reaction (6).

$$
3 \mathrm{Mn}+\mathrm{SO}_{2} \rightarrow \mathrm{MnS}+2 \mathrm{MnO} \Delta \mathrm{G}^{\mathrm{o}}=-538,546 \mathrm{~kJ}
$$

Manganese oxide $(\mathrm{MnO})$ that was formed may react with chromium oxide $\mathrm{Cr}_{2} \mathrm{O}_{3}$ forming the spinel $\mathrm{MnCr}_{2} \mathrm{O}_{4}$.

Chromium oxide and manganese oxide are stable enough not to enter into a reaction with $\mathrm{SO}_{2}$ under the conditions of the conducted process.

\section{Conclusions}

On the basis of the conducted studies it may be established that:

1. The scale thickness depends only on the time of the process duration, and does not depend on the atmosphere composition used in this experiment.

2. The scale formed demonstrates good adherence to the metallic core.

3. The scale is composed of a mixture of chromium oxide $\left(\mathrm{Cr}_{2} \mathrm{O}_{3}\right)$ and the manganese-chromium spinel $\left(\mathrm{MnCr}_{2} \mathrm{O}_{4}\right)$ and on the upper part of scale the $\mathrm{MnS}$ was identified.

4. Within the temperature range of $600-900{ }^{\circ} \mathrm{C}$ the scale is composed of two layers: the outer of the spinel, the inner of chromium oxide.

5. The presence of sulphur was established only on the outer surface of the scale layer, and its presence was not detected within the scale and in the zone of internal oxidation.

6. In the near-surface area of the metallic core the presence of a zone of internal oxidation was identified.

Acknowledgments This work was conducted within the project 3466/B/T02/2008/35 financed by the Ministry of Science and Higher Education. The authors wish to express their gratitude to W.J. Qadakkers, D.Sc., for providing access to research materials. The analyses of the scale morphology partially were carried out in the Foundry Research Institute in Krakow.

Open Access This article is distributed under the terms of the Creative Commons Attribution Noncommercial License which permits any noncommercial use, distribution, and reproduction in any medium, provided the original author(s) and source are credited.

\section{References}

1. W. J. Quadakkers, J. Nicholls, D. Naumenko, J. Wilber, and L. Singheiser, in Materials Aspects in Automotive Catalytic Converters, ed. H. Bode (Wiley-VCH Verlag GmbH \& Co., KGaA, Weinheim, FRG, 2003). 
2. S. M. Haile, Acta Materialia 51, 5981 (2003).

3. W.J. Quadakkers, T. Malkow, J. Piron Abellan, U. Flesch, V. Shemet, and L. Singheiser, in Proceedings 4th European Solid Oxide Fuel Cell Forum, Vol. 2 (Oberrohdorf, Switzeraland, 2000), p. 827.

4. P. Huczkowski and W.J. Quadakkers, Schriften des Forschungszentrum Julich, Energy Technology 65 (2007).

5. J. Quadakkers, J. Piron Abellan, V. Shemet, and L. Singheiser, Materials at High Temperatures 20, 115 (2003).

6. D. R. Peterson and J. Winnick, Journal of Electrochemical Society 145, 1449 (1998).

7. M. Homa, Ph.D. Thesis, 2004.

8. FactSage-Integrated Thermodynamic Databank System, produced by CRCT-Thermfact Inc. and GTT-Technologies.

9. P. Huczkowski, N. Christiansen, V. Shemet, L. Niewolak, J. Piron-Abellan, L. Singheiser, and W. J. Quadakkers, Fuel Cells 06 2, 93 (2006).

10. J. E. Hammer, S. J. Laney, R. W. Jackson, K. Coyne, F. S. Pettit, and G. H. Meier, Oxidation of Metals 67 (2007).

11. W. J. Quadakkers, J. Piron-Abellan, V. Shemet, and L. Singheiser, Materials at High Temperatures 20, 115 (2003). 